Commentary

\title{
Comentário
}

\section{Physical Exercise, Cognitive Performance, Affective Responses and Mental Health: Challenges and Perspectives}

\section{Exercício físico, desempenho cognitivo e saúde mental: perspectivas e desafios}

\author{
Andrea Camaz Deslandes ${ }^{\S 1} \mathrm{PhD} ;$ Tony Meireles dos Santos ${ }^{2} \mathrm{PhD}$
}

Recebido em: 10 de junho de 2017. Aceito em: 12 de junho de 2017.

Publicado online em: 30 de junho de 2017.

\begin{abstract}
Introduction: The prophylactic and therapeutic effects of physical exercise in cardiovascular and metabolic diseases are recognized. In the last ten years, studies have shown the association of active lifestyle with prevention and treatment of mental illnesses as well as the improvement of executive functions throughout life. Nevertheless, methodological problems make it difficult to use the evidence on practical clinic.

Objective: To analyze recent evidence on the effects of physical exercise for cognitive performance improvement, prevention and treatment of mental illness and affective responses generated by exercise, highlighting the gaps that should be fulfilled and challenges on this knowledge area.

Conclusion: Physical exercise contributes to reduce risks for mental illness and to enhance clinical response in patients with mood and anxiety disorders, and neurodegenerative diseases. Cognitive function, mainly executive functions, has been observed in different age groups. Affective responses generated during the exercise are influenced by various extrinsic and intrinsic factors and can contribute to the development of new prescription strategies to increase physical exercise adherence. Studies with greater methodological rigor and variable exercise prescriptions, like frequency, duration, intensity and the type of the exercise should be conduced for better targeting practical application of the knowledge.
\end{abstract}

Keywords: physical activity, neuroscience, affective responses, mental illness, executive function.

\section{Resumo}

Introdução: 0 efeito profilático e terapêutico do exercício físico em doenças cardiovasculares e metabólicas é reconhecido. Nos últimos dez anos, estudos mostraram associação entre o estilo de vida ativo e a prevenção e o tratamento de doenças mentais, assim como, a melhora das funções executivas em diferentes faixas etárias. Entretanto, questões metodológicas dificultam a utilização das evidências na prática clínica.

Objetivo: Apresentar as evidências recentes sobre o efeito do exercício físico na melhora do desempenho cognitivo, prevenção e tratamento de doenças mentais e respostas afetivas geradas pelo exercício, destacando lacunas a serem investigadas e desafios nessa área de conhecimento.

\footnotetext{
${ }^{\S}$ Corresponding Author: Andrea Camaz Deslandes - e-mail: camazdeslandes@gmail.com.

Affiliations: ${ }^{1}$ Laboratory of Exercise Neuroscience, State University of Rio de Janeiro, Brazil; ${ }^{2}$ Department of Physical Education of the Federal University of Pernambuco, Brazil.
} 
Conclusão: 0 exercício físico contribui para a redução do risco de desenvolvimento de doenças mentais e melhora da resposta clínica de pacientes com transtornos de humor e de ansiedade e doenças neurodegenerativas. A melhora da função cognitiva, em especial as funções executivas, é observada em diferentes faixas etárias. As respostas afetivas geradas durante o exercício são influenciadas por diversos fatores extrínsecos e intrínsecos e podem contribuir para o desenvolvimento de novas estratégias de prescrição para a melhora da aderência ao exercício físico. Estudos com maior rigor metodológico e maior controle de variáveis de prescrição de exercícios, como frequência, duração, intensidade e tipo de exercício devem ser feitos para o melhor direcionamento da aplicação prática do conhecimento.

\section{Pontos-Chave Destaque}

- Existe a necessidade de trazer

evidências científicas para a

clínica prática.

- O exercício físico contribui

para reduzir os riscos de

doenças mentais e melhora a

função cognitiva.

- Estudos com maior rigor

metodológico focalizando

respostas afetivas durante 0

exercício são necessários.

Palavras-chave: atividade física, neurociência, respostas afetivas, doença mental.

\section{Physical Exercise, Cognitive Performance, Affective Responses and Mental Health: Challenges and Perspectives}

According to the International Charter of Physical Education, Physical Activity and Sport (1978), every human being has the fundamental right of access to physical exercise and sport, which are essential for full development of personality. Among the effects of physical exercise, children physically active have a lower risk of becoming smokers, developing cardiovascular and metabolic diseases on adult life, and physical active childhood increases the chances of professional and academic success throughout life, with higher probability of access to the university and higher income. The benefits of exercise go beyond childhood - being physically active throughout life reduces physical and mental illness risks, promotes longevity and contributes to several diseases treatment $(1,2)$.

Despite the evidence on the prophylactic and therapeutic effects of physical exercise, most the population does not perform 150 minutes of physical exercise moderated per week, recommendations of the World Health Organization (WHO). A recent populational study, using accelerometers $(\mathrm{N}=4,773)$ showed that only $9.6 \%$ of the Americans achieved that level of weekly physical activity(3). Among 13-15 years old adolescents approximately $80 \%$ does not perform 60 minutes of moderated physical exercise per day(4). Physical inactivity is considered one of the major problems related to health of the XXI century(5). The lack of pleasure and interest on performing physical exercises has been pointed out as a limiting factor to the maintenance of an active lifestyle. On the other hand, research on pleasure and positive affective responses during and immediately after a single exercise session can contribute to the comprehension of associated factors with adherence $(6,7)$. This article analyses recent evidence on the relationship between physical exercise and the cognitive performance, prevention and treatment of mental illness, and the relationship between physical exercise and affective responses.

\section{Physical Exercise and Cognitive Function}

Physical exercise promotes various neurological alterations that can contribute to improve cognitive performance and mental health. Among the main adaptations observed, 
the higher production and release of monoamines (e.g., serotonin, dopamine, norepinephrine) and trophic factors (e.g., brain derived neurotrophic factor, insulin-like growth factor-1, vascular endothelial growth factor) that contribute to increase neurogenesis and angiogenesis in hippocampal areas are highlighted(8-11). Hence, it is expected that physical exercise promotes neuroplasticity favoring new memories and learning. Studies have shown that physical exercise leads to improvement on cognitive functions(12). This effect is observed specially on open tasks - those performed in an unpredictable environment, which require cognitive engagement physical exercise seem to potentiate these responses(13). The benefits of physical exercise to the cerebral activities are numerous. For example, during activities like sportive games, fights and outdoor activities it is necessary to sense the sensory stimuli, decision making, select responses and program the ideal motor response to every situation. This process of information promotes the higher stimulation of areas like the frontal and parietal cortex, fundamental to the performance of activities that involves attention, perception, inhibitory control, work memory, visuospatial memory, and program of the ideal motor response, with the definition of parameters like speed, strength, amplitude and direction of the movement. The development of the executive functions contributes to the higher chance of emotional, professional and economic success, besides being associated to better quality of life and mental health(14). In this context, the evidences point out to the improvement of academic achievement on children(15) and the improvement of the executive function on elders(16). However, the great variability of cognitive outcomes and the methodological differences related to the prescription of exercise (duration, type, intensity), makes the evidence observed just weak(16-18), making it difficult to use the knowledge into practice.

\section{Physical Exercise and Mental Illness}

Mental illness is highly incapacitating and associates with inflated costs to society.
Among the most prevalent mood disorders, depression is observed in all age groups and increases the lost days caused by incapacity and premature death being one of the causes of suicide. According to the WHO, every 40 seconds someone in the world dies by suicide.

Besides mental disorders, neurodegenerative diseases are a challenge to the elderly population, and the most prevalent ones are dementia. According to World Alzheimer Report (2015), a new dementia case is expected every three seconds. As country, the total of costs of dementia would be the equivalent of the 18th largest economy in the world with market values bigger than companies like Google and Apple. In this perspective, physical exercise is pointed as a lifestyle factor that can contribute to the reduction of the global burden of diseases also related to mental illness. Physical exercise reduces risks for. of the Mild Cognitive Impairment (35\%); depression (59\%); Alzheimer's disease (51\%); and vascular dementia $(40 \%)(19-22)$. Besides the protective effect on mental functions, studies showed improvement on clinical responses to treatments with practice of physical exercises as coadjuvant therapy, despite having little effect $(23,24)$. Studies exhibited in the literature present methodological problems such as diagnosis and severe of symptoms, prescription of exercise, intention-to-treat analysis, and control group active $\mathrm{x}$ nonactive, which can reduce the effect size of physical exercise on recent meta-analyses. Therefore, it needs to be carefully examined(25). The aerobic training with moderated and continuous intensity was the most investigated aspect, on patients in the early stages of the disease(8,26-28). However, recent studies show the benefic effect of other interventions like strength training, yoga, tai-chi, and multimodal exercises(26-31). Despite the promising results, problems like the relation doseresponse, the determinant factors of adherence to exercise on such populations, and better exercise configurations to each disease are unsolved issues that need to be more investigated. 
Affective responses during and immediately after an exercise session: looking for higher adherence

The acute effect of pleasure as a causal or mediating variable should also be considered for mental health, measured traditionally by "core valence affect" during physical exercise, a construction under the hedonic theory of motivation(32). Studies have shown that pleasure during exercise increases a future exercise behavioral and adherence(7). An important dilemma to be considered it is affect assessment, traditionally linked to scales. Due to some cognitive characteristics, the face recognition strategies could be considered as an alternative approach. Thus, we suggest the inclusion of 'feel good' moments replacing 'feel bad' moments questions. To promote 'feel good' activities with adequately scientific support should include: a) Adjustment in exercise intensity (below the first ventilatory threshold in a continuous activity it is more enjoyable) and duration of activity; b) Music listening during exercise sessions(33); c) Virtual reality(34); and d) Self-selected type and intensity of activity(35). Considering the effects of dissociations thinking's during the task(36), future studies should explore the benefits of playfulness in sportive games who also intensify cognitive stimulus (dual / multiple tasks). This context should be considered as a promissory way to rethink exercise interventions more than simply 'medicine', but as a celebration and enjoyment relevant moment to improve adherence.

\section{Conclusion}

In the last twenty years, the improvement of cognitive performance and mental health with physical exercise has been the subject of investigations and the results are promising, with evidence of a protecting factor of the active lifestyle on most disability and prevalent mental illness, like mood disorders and neurodegenerative diseases. However, intervention studies with high methodological rigor, especially with high control of exercise prescription are required. In exercise and sports sciences, among challenges is adherence, which is one of the most urgent question. For better understand the phenomenon, it is necessary to comprehend preference matters, previous experience, personality, and affective responses during the exercise. Cost-effectiveness studies of the intervention with exercise are necessary for a better comprehension of the role of exercise on mental illness treatment related to costs reduction, and the awareness of public health politics and researches on the knowledge areas.

Neuroscience through the neuroimaging techniques, biomarkers, neuropsychological tasks and scales contributes to the better comprehension of the physical exercise's mechanisms of action of on the brain. Investigation on this area requires the integration of the knowledge and interdisciplinary work of physical education with psychology, medicine, biology and biochemistry. It is time to replace the dualist physical education, that separates body from mind, for a holistic vision of the human being and the movement full of possibilities for interactions.

\section{Funding statement}

The present study was partially supported by the National Council for Scientific and Technological Development (Conselho Nacional de Desenvolvimento Científico e Tecnológico: CNPq) - Scholarship Productivity $\mathrm{Pq} 2$ ) and Carlos Chagas Filho Foundation for Research Support of the State of Rio de Janeiro (Fundação Carlos Chagas Filho de Amparo à Pesquisa do Estado do Rio de Janeiro - FAPERJ) Young Scientist's Scholarship.

\section{References}

1. Lee D-C, Brellenthin AG, Thompson PD, Sui X, Lee I-M, Lavie CJ. Running as a Key Lifestyle Medicine for Longevity. Progress in Cardiovascular Diseases. [Online] 2017; Available from: doi:10.1016/j.pcad.2017.03.005

2. Fiuza-Luces C, Garatachea N, Berger NA, Lucia A. Exercise is the real polypill. Physiology (Bethesda, Md.). [Online] 
2013;28(5): 330-358. Available from: doi:10.1152/physiol.00019.2013

3. Tucker JM, Welk GJ, Beyler NK. Physical activity in U.S.: adults compliance with the Physical Activity Guidelines for Americans. American Journal of Preventive Medicine. [Online] 2011;40(4): 454-461. Available from: doi:10.1016/j.amepre.2010.12.016

4. Hallal PC, Andersen LB, Bull FC, Guthold R, Haskell W, Ekelund U, et al. Global physical activity levels: surveillance progress, pitfalls, and prospects. Lancet (London, England). [Online] 2012;380(9838): 247-257. Available from: doi:10.1016/S0140-6736(12)60646-1

5. Trost SG, Blair SN, Khan KM. Physical inactivity remains the greatest public health problem of the 21 st century: evidence, improved methods and solutions using the ' 7 investments that work' as a framework. British Journal of Sports Medicine. [Online] 2014;48(3): 169-170. Available from: doi:10.1136/bjsports2013-093372

6. Williams DM, Dunsiger S, Ciccolo JT, Lewis BA, Albrecht AE, Marcus BH. Acute Affective Response to a Moderateintensity Exercise Stimulus Predicts Physical Activity Participation 6 and 12 Months Later. Psychology of Sport and Exercise. [Online] 2008;9(3): 231-245. Available from: doi:10.1016/j.psychsport.2007.04.002

7. Rhodes RE, Kates A. Can the Affective Response to Exercise Predict Future Motives and Physical Activity Behavior? A Systematic Review of Published Evidence. Annals of Behavioral Medicine: A Publication of the Society of Behavioral Medicine. [Online] 2015;49(5): 715-731. Available from: doi:10.1007/s12160-0159704-5

8. Deslandes A, Moraes H, Ferreira C, Veiga $\mathrm{H}$, Silveira H, Mouta R, et al. Exercise and mental health: many reasons to move. Neuropsychobiology. 2009;59(4): 191198.
9. van Praag H, Christie BR, Sejnowski TJ, Gage FH. Running enhances neurogenesis, learning, and long-term potentiation in mice. Proceedings of the National Academy of Sciences of the United States of America. 1999;96(23): 13427-13431.

10. Dishman RK, Berthoud H-R, Booth FW, Cotman CW, Edgerton VR, Fleshner $\mathrm{MR}$, et al. Neurobiology of exercise. Obesity (Silver Spring, Md.). [Online] 2006;14(3): 345-356. Available from: doi:10.1038/oby.2006.46

11. Deslandes AC. Exercise and Mental Health: What did We Learn in the Last 20 Years? Frontiers in Psychiatry. [Online] 2014;5: 66. Available from: doi:10.3389/fpsyt.2014.00066

12. Hillman $\mathrm{CH}$, Erickson KI, Kramer AF. Be smart, exercise your heart: exercise effects on brain and cognition. Nature Reviews. Neuroscience. [Online] 2008;9(1): 58-65. Available from: doi:10.1038/nrn2298

13. Diamond A. Activities and Programs That Improve Children's Executive Functions. Current Directions in Psychological Science. [Online] 2012;21(5): 335-341. Available from: doi:10.1177/0963721412453722

14. Diamond A. Executive functions. Annual Review of Psychology. [Online] 2013;64: 135-168. Available from: doi:10.1146/annurev-psych-113011143750

15. Fedewa AL, Ahn S. The effects of physical activity and physical fitness on children's achievement and cognitive outcomes: a meta-analysis. Research Quarterly for Exercise and Sport. [Online] 2011;82(3): 521-535. Available from: doi:10.1080/02701367.2011.10599785

16. Kelly ME, Loughrey D, Lawlor BA, Robertson IH, Walsh C, Brennan S. The impact of exercise on the cognitive functioning of healthy older adults: a systematic review and meta-analysis. Ageing Research Reviews. [Online] 
2014;16: 12-31. Available from: doi:10.1016/j.arr.2014.05.002

17. Donnelly JE, Hillman CH, Castelli D, Etnier JL, Lee S, Tomporowski $\mathrm{P}$, et al. Physical Activity, Fitness, Cognitive Function, and Academic Achievement in Children: A Systematic Review. Medicine and Science in Sports and Exercise. [Online] 2016;48(6): 1223-1224. Available from: doi:10.1249/MSS.0000000000000966

18. Young J, Angevaren M, Rusted J, Tabet N. Aerobic exercise to improve cognitive function in older people without known cognitive impairment. The Cochrane Database of Systematic Reviews. [Online] 2015;(4): CD005381. Available from:

doi:10.1002/14651858.CD005381.pub4

19. Blondell SJ, Hammersley-Mather R, Veerman JL. Does physical activity prevent cognitive decline and dementia?: A systematic review and meta-analysis of longitudinal studies. BMC public health. [Online] 2014;14: 510. Available from: doi:10.1186/1471-2458-14-510

20. Barcelos-Ferreira R, Pinto JA, Nakano EY, Steffens DC, Litvoc J, Bottino CMC. Clinically significant depressive symptoms and associated factors in community elderly subjects from Sao Paulo, Brazil. The American Journal of Geriatric Psychiatry: Official Journal of the American Association for Geriatric Psychiatry. [Online] 2009;17(7): 582-590. Available from: doi:10.1097/JGP.0b013e3181a76ddc

21. Beckett MW, Ardern CI, Rotondi MA. A meta-analysis of prospective studies on the role of physical activity and the prevention of Alzheimer's disease in older adults. BMC geriatrics. [Online] 2015;15: 9. Available from: doi:10.1186/s12877015-0007-2

22. Aarsland D, Sardahaee FS, Anderssen S, Ballard C, Alzheimer's Society Systematic Review group. Is physical activity a potential preventive factor for vascular dementia? A systematic review. Aging \& Mental Health. [Online] 2010;14(4): 386-395. Available from: doi:10.1080/13607860903586136

23. Forbes D, Thiessen EJ, Blake CM, Forbes SC, Forbes S. Exercise programs for people with dementia. The Cochrane Database of Systematic Reviews. [Online] 2013;(12): CD006489. Available from: doi:10.1002/14651858.CD006489.pub3

24. Cooney GM, Dwan K, Greig CA, Lawlor DA, Rimer J, Waugh FR, et al. Exercise for depression. The Cochrane Database of Systematic Reviews. [Online] 2013;(9): CD004366. Available from: doi:10.1002/14651858.CD004366.pub6

25. Ekkekakis P. Honey, I shrunk the pooled SMD! Guide to critical appraisal of systematic reviews and meta-analyses using the Cochrane review on exercise for depression as example. Mental Health and Physical Activity. [Online] 2015;8: 21-36. Available from: doi:10.1016/j.mhpa.2014.12.001

26. Silveira $H$, Moraes $H$, Oliveira $N$, Coutinho ESF, Laks J, Deslandes A. Physical exercise and clinically depressed patients: a systematic review and metaanalysis. Neuropsychobiology. [Online] 2013;67(2): 61-68. Available from: doi:10.1159/000345160

27. Groot C, Hooghiemstra AM, Raijmakers PGHM, van Berckel BNM, Scheltens P, Scherder EJA, et al. The effect of physical activity on cognitive function in patients with dementia: A meta-analysis of randomized control trials. Ageing Research Reviews. [Online] 2016;25: 13-23. Available from: doi:10.1016/j.arr.2015.11.005

28. Carvalho A, Barbirato D, Araujo N, Martins JV, Cavalcanti JLS, Santos TM, et al. Comparison of strength training, aerobic training, and additional physical therapy as supplementary treatments for Parkinson's disease: pilot study. Clinical Interventions in Aging. [Online] 2015;10: 
183-191. Available from: doi:10.2147/CIA.S68779

29. Zhou J, Yin T, Gao Q, Yang XC. A Meta-Analysis on the Efficacy of Tai Chi in Patients with Parkinson\&\#x2019; Disease between 2008 and 2014. EvidenceBased Complementary and Alternative Medicine. [Online] 2015;2015: e593263. Available from: doi:10.1155/2015/593263

30. Ahmadi A, Arastoo AA, Nikbakht M, Zahednejad S, Rajabpour M. Comparison of the Effect of 8 weeks Aerobic and Yoga Training on Ambulatory Function, Fatigue and Mood Status in MS Patients. Iranian Red Crescent Medical Journal. [Online] 2013;15(6): 449-454. Available from: doi:10.5812/ircmj.3597

31. de Andrade LP, Gobbi LTB, Coelho FGM, Christofoletti G, Costa JLR, Stella F. Benefits of multimodal exercise intervention for postural control and frontal cognitive functions in individuals with Alzheimer's disease: a controlled trial. Journal of the American Geriatrics Society. [Online] 2013;61(11): 1919-1926. Available from: doi:10.1111/jgs.12531

32. Ekkekakis P, Parfitt G, Petruzzello SJ. The pleasure and displeasure people feel when they exercise at different intensities: decennial update and progress towards a tripartite rationale for exercise intensity prescription. Sports Medicine (Auckland, N.Z.). [Online] 2011;41(8): 641-671. Available from: doi:10.2165/11590680000000000-00000

33. Jones L, Karageorghis CI, Ekkekakis P. Can high-intensity exercise be more pleasant?: attentional dissociation using music and video. Journal of Sport \& Exercise Psychology. [Online] 2014;36(5): 528-541. Available from: doi:10.1123/jsep.2014-0251

34. Moyle W, Jones C, Dwan T, Petrovich T. Effectiveness of a Virtual Reality Forest on People With Dementia: A Mixed Methods Pilot Study. The Gerontologist. [Online] 2017; Available from: doi:10.1093/geront/gnw270
35. Ekkekakis P. Let them roam free? Physiological and psychological evidence for the potential of self-selected exercise intensity in public health. Sports Medicine (Auckland, N.Z.). [Online] 2009;39(10): 857-888. Available from: doi:10.2165/11315210-000000000-00000

36. Lind E, Welch AS, Ekkekakis P. Do 'mind over muscle' strategies work? Examining the effects of attentional association and dissociation on exertional, affective and physiological responses to exercise. Sports Medicine (Auckland, N.Z.). [Online] 2009;39(9): 743-764. Available from: doi:10.2165/11315120000000000-00000 